\title{
Examining the Mechanisms Utilized by CML Web-Logging Instructors in ESL Classroom: A Case Study
}

\author{
Noriah Ismail \\ Academy of Language Studies, Universiti Teknologi MARA Cawangan Johor, Malaysia \\ Supyan Hussin \\ Faculty of Social Sciences and Humanities, Universiti Kebangsaan Malaysia, Malaysia \\ Rehab Omar Salem Aboswider \\ Faculty of Social Sciences and Humanities, Universiti Kebangsaan Malaysia, Malaysia \\ email:noriah27@gmail.com,noreezphd1@gmail.com
}

DOI: https://doi.org/10.37134/ajelp.vol7.2.4.2019

Cite this article (APA): Ismail, N., Hussin, S., \& Aboswider, R. O. (2019). Examining the Mechanisms Utilized by CML Web-Logging Instructors in ESL Classroom: A Case Study. AJELP: Asian Journal of English Language and Pedagogy, 7(2), 31-39. https://doi.org/10.37134/ajelp.vol7.2.4.2019

\begin{abstract}
The current study seeks to explore six Malaysian ESL instructors use of CML Web-logging in teaching English as second language to Malaysian students at higher education institutions. A qualitative approach was adopted to collect responses from the respondents. Data were collected using semi-structured interview, a set of questionnaires as well as a checklist of features of the web blog that is used to investigate the blogging activities and mechanisms used in the courses conducted by the respondents. The collected data from the interview were analyzed qualitatively, whereas the blog checklist data were analyzed quantitatively. The results indicated that in order to enhance their ESL instruction, the CML WebBlogging instructors not only exhibited special ways of using the technology but they also designed various methods of exploiting the educational web blog capabilities in order to accommodate their pedagogical purposes and suit their specific course objectives.
\end{abstract}

Keywords: Web-logging, ESL, Writing

\section{INTRODUCTION}

The popularity of Computer-Mediated Learning or CML web-based learning systems is attributed to the various benefits they offer both the instructor and the learner, such as cost- 
effectiveness, paperless environment, accessibility regardless to geographical location and time restrictions and less dependence on the instructor. These advantages have gained web-based learning systems a momentum in the information society, and led many universities and private corporations to invest significant capital in online training programs and internet-based education (Allen \& Seaman, 2005; Mohammadi et al. 2011). Although many Web networking technologies available today are well established and used widely, the adoption of blogs for learning in the contemporary education, let alone learning English language, has been generally slow. Therefore, the current study comes to cast into this end and fill the gap in knowledge. The research presented in this thesis is in line with the recent trend in integrating Internet accessible technology of Web logging in second language education.

\section{LITERATURE REVIEW}

Modern approaches of second language education entitle instructors to restructure their old approaches and embrace Web-based systems in learning and cognitive activities with the aim of developing the study skills and growing knowledge in students (Warschauer, 2010; Noriah Ismail et al., 2015). Research indicates that Computer Mediated Learning (CML) contributed a significant role for language teaching and developing study skills in learners (Mohammadi et al. 2011; Noriah Ismail et al., 2013). As a result, the number of students enrolling in online language courses is increasing exponentially on yearly basis. Moreover, many language teaching institutions demand experience in or familiarity with computer and Internet technologies as a requirement for hiring competent instructors. These new pedagogical developments entitle contemporary second language educationists to equip themselves with necessary skills to use Web technologies effectively and efficiently in order to match the expectations of both education organizations and modern learners and to enhance their professional competence.

Among various Web technologies applied in education, recent trends indicate that network application of blogging is increasingly being accepted as transformational instructional technology tool in universities and schools. Blogs become a profound figure in the present Internet landscape, and due to their distinctive features which set them apart from early asynchronous discussion technologies, they have lately drawn attention in the academic arena (Top, 2010). In education context, blogs promote active and student-centered learning (Beale 2007; Noriah Ismail et al., 2015). Students find blogging useful and effective addition to their learning because the technology enables them to make contributions to the class, promotes peer learning, and encourages quality in work (Zawilinski, 2009). When the instructor integrated blogs in classroom, students became self-directed, motivated to learn collaboratively, independent thinkers and relying minimally on their instructor. With blogs, students were not learning in isolation; instead, they approached, communicated and socialized with other people of diversified background.

Therefore, it can be observed that from pedagogical point of view, blogs enhance education by encouraging reflective practice in students: they help the students to take the leadership and engage responsibly in executing the learning activities. Xie et al. (2008) asserted that blogging has impact in increasing the reflective learning in students. On the other hand, it also can be seen that blogs help the instructor to create up an optimum setting that assists in monitoring the students in carrying out their learning responsibilities and evaluate the total quality of learning process. Teacher bloggers emphasized that educational 
blogs influence the reading and writing skills in students - capabilities that are vital pillars in formulating literacy competency. This means that blogs, if utilized thoughtfully, have potential impact on developing student's literacy level. However, recent studies (Beale, 2007; Rezaee \& Oladi, 2008; Mohammadi et al. 2011; Noriah Ismail et al., 2016) have been narrowing their focus more to investigate the impact of blogs on improving the writing skills in second language learners.

By struggling with writing or lacking proper writing capabilities, students are unable to engage with text or go through authentic writing experience and so will lag behind (Deepak Singh Ratan Singhet al., 2012). In the Malaysian context, universities demand students to exhibit mastery in English writing skill, among other skills, as a requirement for admission and to ensure students' capability in publishing their research work in international publications. So, educators are always keen to design and apply the most effective techniques that lead to improve the writing skills in their students. To meet this aspiration, some investigators (e.g., Zawilinski 2009) suggested the use of blogs by benefiting from their prominent advantage of combining the publishing and discussion of student writing in a single medium.

In other research (Warschauer 2010) blogs were found helpful in "increasing the quantity of student writing as well as its lexical sophistication" and in training the students to "form a more colloquial to an academic writing style, develop a sense of voice, learn to participate in a community of writers, and gain an important new literacy". Further, because writing symbolizes the effect of connecting the students' work done inside the classroom walls with experiences the students have had outside the classroom environment (Noriah Ismail, et al., 2016); blogs offer the instructor an opportunity to evaluate the students'state of knowledge and thinking process about using English in relation to practical writing; thus adjust instruction as necessary (Warschauer, 2010; Noriah Ismail \& Intan Safinas Mohd Ariff Albakri, 2013).

\section{RESEARCH METHODOLOGY}

The research methodology adopted in the present study relied on a qualitative assessment approach to explore and develop knowledge on the instructor's perception and specific techniques employed on the usage of CML Web-blog technology in English language education. Qualitative methodology was employed in this study because qualitative methods allow the researcher to gain new perspectives on yet-to-know phenomena or gain more in-depth information that may be difficult to convey quantitatively (Creswell, 2008). Non-probability sampling was adopted to suit the qualitative approach set for this study because this particular mode of sampling helps in solving different qualitative problems such as discovering what occurs, the implications of what occurs, and the relationships linking occurrences (Merriam, 1998). To achieve this, six instructors (Identified as ' $R$ '), three males and three females, volunteered themselves to take part in this study. Five of them are from Universiti Kebangsaan Malaysia (UKM), Bangi and and one University Teknologi MARA (UITM), Shah Alam. These instructors have been lecturing in different courses in English Literature, Applied Linguistics and other language related courses for more than fifteen years. The English language instructor bloggers were surveyed by using interview sampling to elicit their personal impression and individual opinion about blog usage in their teaching methodologies. Meanings were discovered 
from their personal experiences and expressed insights and then reported and interpreted qualitatively. In addition, the characteristics of those blogs employed pedagogically by English language instructors were observed, diagnosed, and evaluated by checklist instrument against specific criteria, referred as 'blogging rubrics', describing the blog quality and value to teaching/learning process. An analytical (descriptive) report was prepared for summarizing, visualizing and evaluating the findings of data processing. Graphical representation of the results was used with the aid of SPSS software to facilitate the processes of describing the meaning and significance of interviews and checklist data as well as information inference. The information derived from interviews and blog assessment rubrics were gathered, organized, managed, coded, and analyzed in order to seek answers to the pre-set research questions. Results gathered from blog assessment checklist were used to tackle certain issues relating to technology inclusion in English language education. From these insights, one would come up with general conclusions and suggestions that cast into the development of blog usage in language education in Malaysia.

\section{FINDINGS AND DISCUSSIONS}

This section describes the findings of the study which entail the instructors' use of CML Weblogging in delivering ESL courses. Among the major findings are the interviewed instructors reported different methodologies of employing CML Web-logging or blogs in teaching their courses. Analyzing the interview responses, one could realize that there was no specific procedure of its own in using blogs in teaching since the instructors design their own methodology according to the defined objectives of their courses. However, there were common class instruction techniques used by the teachers with the aid of blogs as reported in the responses of study sample on the checklist survey. Table 4.1 illustrates the different techniques of teaching used in blogs compared to their use in non-blog environments. Figure 4.1 to Figure 4.3 summarize the pedagogical techniques used by the interviewed instructors in teaching their courses via blogs.

Table 4.1: Features of class instruction in the blog

\begin{tabular}{|c|c|c|c|c|c|c|c|c|c|c|c|c|}
\hline \multirow[t]{2}{*}{ Features } & \multicolumn{6}{|c|}{$\begin{array}{l}\text { Available in the } \\
\text { "teaching" blog }\end{array}$} & \multicolumn{6}{|c|}{$\begin{array}{l}\text { Available in other platforms } \\
\text { like email, LMS etc. }\end{array}$} \\
\hline & R1 & $\mathbf{R 2}$ & $\mathbf{R 3}$ & R4 & R5 & R6 & $\mathbf{R} 1$ & $\mathbf{R 2}$ & R3 & R4 & $\mathbf{R 5}$ & R6 \\
\hline Announcement & - & - & l & - & / & / & / & / & - & / & / & / \\
\hline Course synopsis & - & - & / & - & / & / & l & l & - & / & / & / \\
\hline Course schedule & - & - & / & - & / & / & I & / & - & I & / & / \\
\hline Class assignments & - & - & / & - & / & / & l & / & - & / & - & / \\
\hline
\end{tabular}




\begin{tabular}{|c|c|c|c|c|c|c|c|c|c|c|c|c|}
\hline Class notes & - & - & l & - & l & / & l & l & - & l & - & l \\
\hline $\begin{array}{l}\text { Class discussion or } \\
\text { forum }\end{array}$ & - & - & l & l & I & l & l & l & - & - & - & l \\
\hline Tutorials & - & - & l & - & / & l & - & l & - & l & - & I \\
\hline Quiz & - & - & - & - & I & - & - & - & - & l & - & - \\
\hline Reflective journal & - & - & l & - & l & - & - & l & - & - & - & - \\
\hline Review of article & - & I & l & - & l & - & - & l & - & l & - & - \\
\hline $\begin{array}{c}\text { Comments/ responses } \\
\text { by instructors }\end{array}$ & - & - & I & - & / & / & - & / & - & - & - & I \\
\hline $\begin{array}{c}\text { Comments/ responses } \\
\text { by students }\end{array}$ & - & I & l & - & l & l & - & l & - & l & - & I \\
\hline $\begin{array}{l}\text { Use of video } \\
\text { materials }\end{array}$ & - & I & l & - & l & I & - & - & - & l & - & I \\
\hline $\begin{array}{l}\text { Use of audio } \\
\text { materials }\end{array}$ & - & I & l & - & l & - & - & - & - & l & - & l \\
\hline $\begin{array}{c}\text { Use of } \\
\text { pictures/photos }\end{array}$ & - & I & l & - & l & l & - & - & - & I & - & l \\
\hline Use of graphics & - & I & / & - & l & I & - & - & - & I & - & I \\
\hline Use of animations & - & I & / & - & l & l & - & - & - & l & - & I \\
\hline $\begin{array}{c}\text { Links to other blogs } \\
\text { and websites }\end{array}$ & - & I & I & I & 1 & I & - & - & - & - & - & I \\
\hline
\end{tabular}




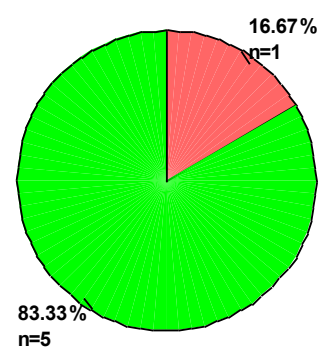

Links to other blogs and websites No
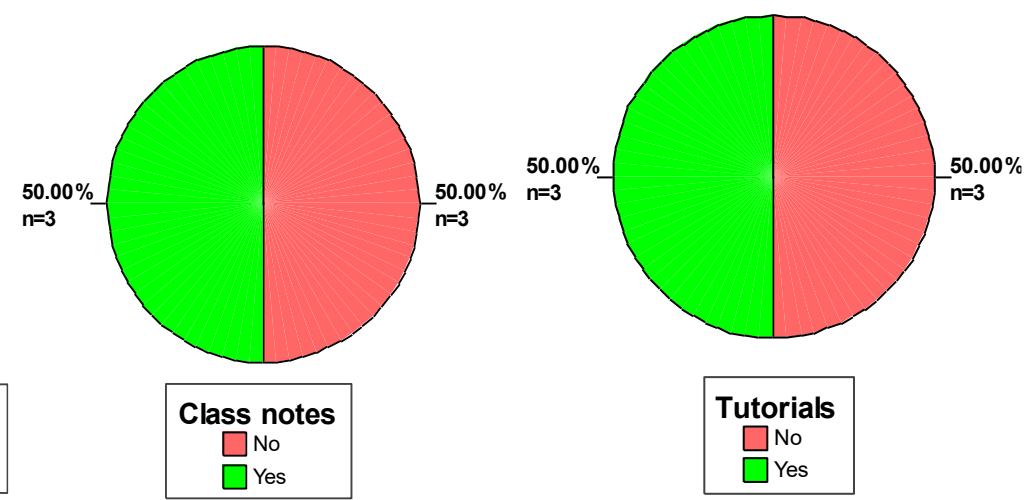

Tutorials

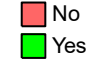

Figure 4.1 Contents for course in the blog
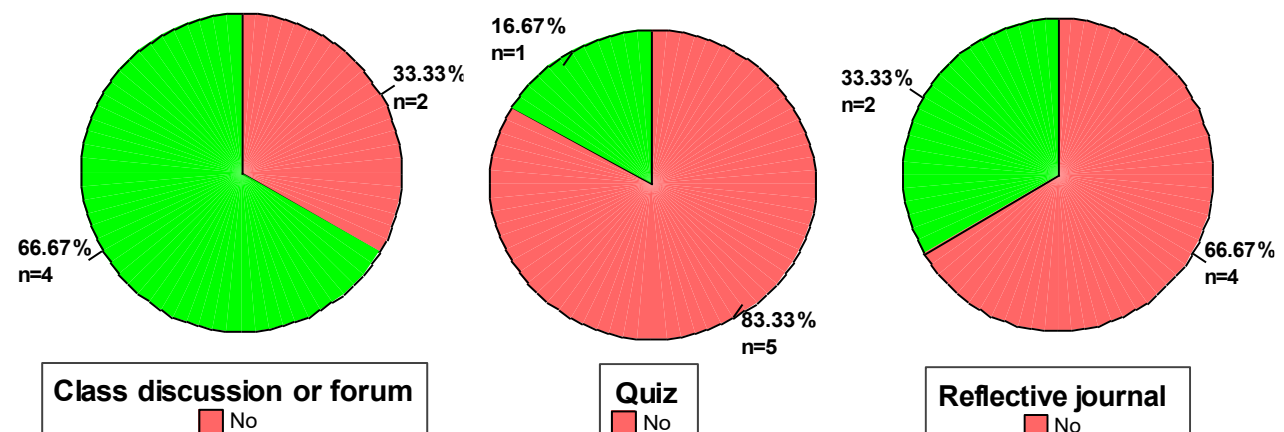
$\square$ No

$\square$ Yes
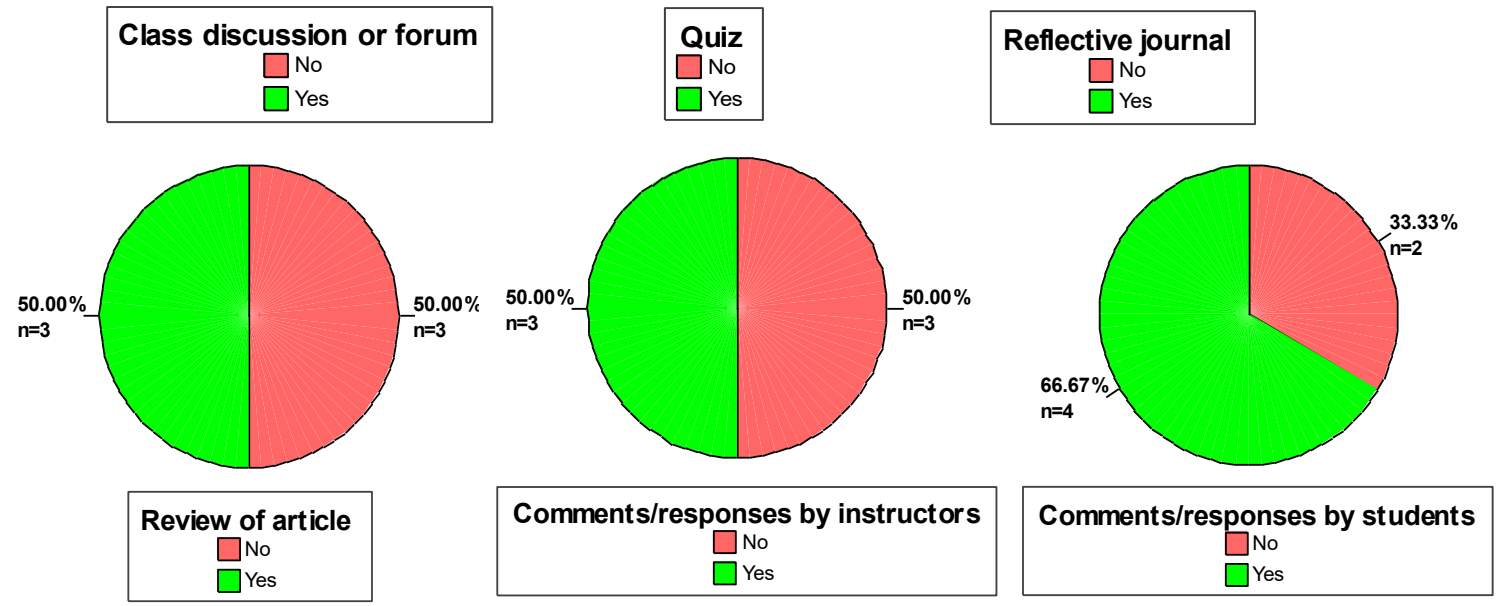

Figure 4.2 Interaction between the teacher and students and among students 

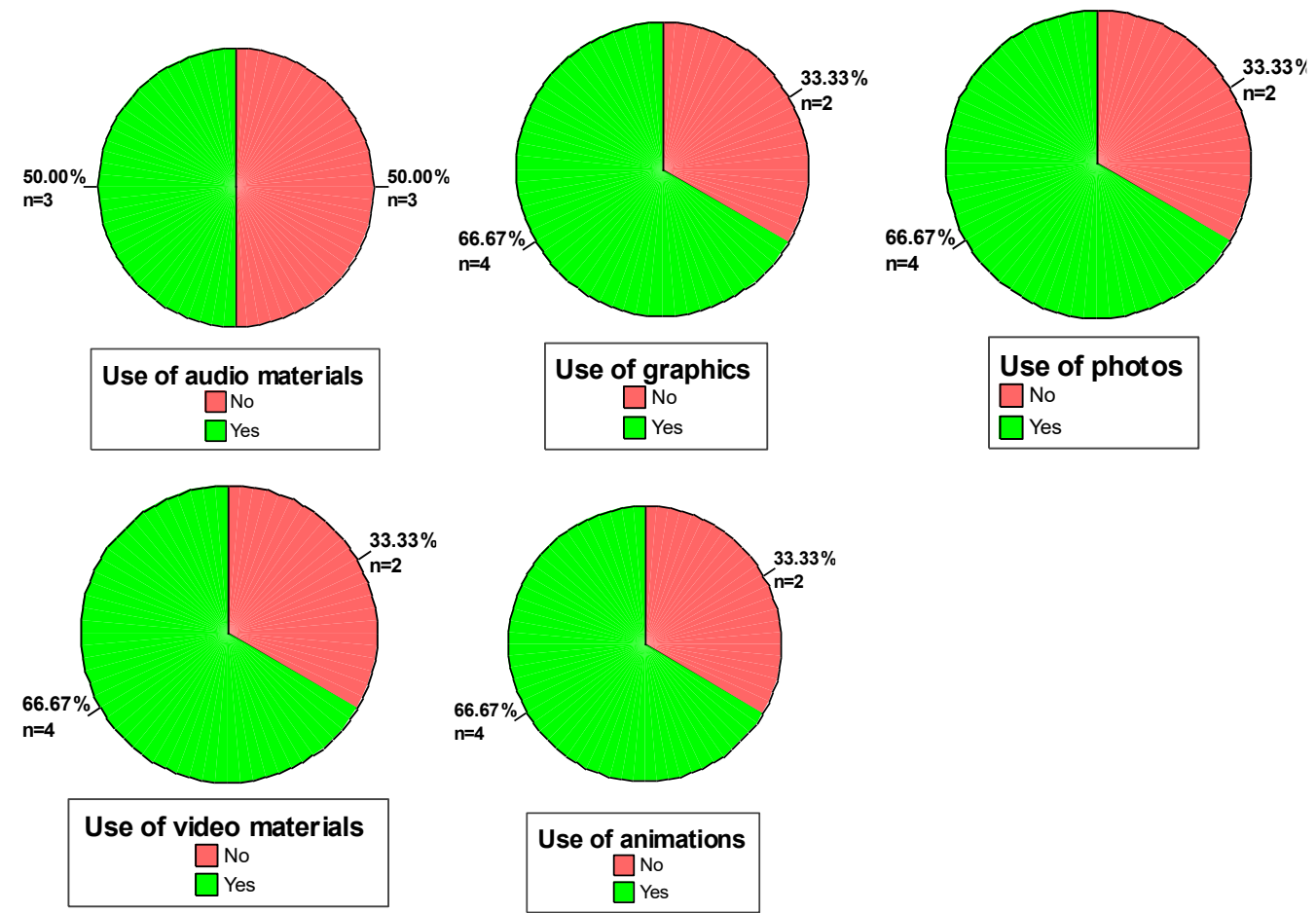

Figure 4.3 Multimedia elements used in the blog

From the above tables and the figures, it can be seen that there are a host of techniques that were fairly used by the sampled instructors; but apparently, the mostly preferred teaching techniques were the followings: class discussion, commenting, links to exterior resources, animations, graphics, photos and video materials. Alternatively, the least used techniques were quizzes and reflective journals. R5 respondents justified avoiding quizzes by stating the following: "The quizzes are not suitable for my post-graduate course which emphasizes applications of theory and principles, and not memorization of facts, formulas or principles." In addition, the instructors pointed that some of the reported teaching techniques used via blogs were also used partially in non-blog platforms, such as Emails and LMS-SPIN, but blogs allowed wide usage of most of the techniques.

\section{Purposes of Blog-Based Instruction Techniques}

Interviewed instructors expressed they allowed students to freely add other products from nontraditional resources, e.g., students' presentations and products from their own arts (pictures and videos captured from their handset electronic mobile devices), in their blogs that support their discussions and efforts towards learning. This exercise revealed the creativity, sense of responsibility, criticality and ambition for knowledge discovery in students. In this respect, R4 respondent stated that: "They do it (on) their own, they create their own and do it inside (their blogs) and also go outside classroom) and learn about that and they find that there is so much more to know." 


\section{Teachers' and Students' Responses to Postings}

Analyzing the interview responses on the teacher's behavior in responding to student's posts, one can give the following observations:

1. Majority of surveyed teachers kept their responses to student posts within the blog environment; only in one case (R2 respondent) there was advanced mode of teacher's response through sending emails to students.

2. Teachers were responding with minimal level of feedback to students' posts. One respondent (R4) stated that: "My comment is very limited". Some teachers attributed this shortage to the limitless of their time schedule which was sensed in the response of R6 participant: "I look to the comment if it is urgent means they do not know at all, and then I would (respond). But every time I respond to such it may take a lot of my time."

3. The forms of teachers' responses included giving short comments, suggestions and praises on students' posts, answering to students' inquiries, correcting language mistakes, marking the posts and instilling questions within the students' posts to trigger further, deep discussion. One instructor (R5 respondent) reported the following:

"I browse students' responses and if necessary, I will respond especially when students misunderstood the basic concepts, when they are not about certain issues or answers they gave, and when they have opposing views. Sometime I trigger questions to get them into a deeper discussion on a particular issue."

\section{Assessment in the Blog}

Interviewed instructors implied in their responses that their assessment of students' works and assignments was carried out on the teaching blog as well as through emails and LMS-SPIN. Another distinctive feature was readily sensed from interview responses: most of the interviewed teachers did not put weight for the language outputs in students' writing when marking their posts (except for R6 respondent who believed that assessment of English proficiency in students' writing is necessary). The students' participation and contribution to the blog discussion were the most important factors behind the writing process, because it leads to student motivation at the first instance. R5 respondent emphasized that "I do expect my students to write well in their posting but I don't grade their language output in the postings....their active participation and substantial input are important than their language outputs".

\section{CONCLUSION}

Based on the findings of this study, it can be concluded that the status of using blogs in Malaysian universities for second language education is reliable and effective. The instructors in this study perceived blogs as a suitable tool for developing the learning and teaching of English language to Malaysian students. The endeavors of integrating blogs in language teaching received positive reflection from the surveyed teachers: they found blog-based education systems feasible, practical and serving both the teacher and the student in achieving the desired 
objectives. The surveyed teachers exhibited different attitudes and creativity in setting the purposes and designing suitable pedagogical methodology of applying blogs in their teaching techniques and in accommodating the technology for their efforts of enhancing English skills in the Malaysian learners.

\section{REFERENCES}

Beale, R. (2007). Blogs, reflective practice and student-centered learning. Proceedings of the 21st BCS HCI Group Conference, 3-7 September, UK.

Creswell, John. W. (2009). Research Design: Qualitative, Quantitative, and Mixed Methods Approaches. $3^{\text {rd }}$ edition. Thousand Oaks, California: SAGE Publications. Ind.

Deepak Singh Ratan Singh, Noriah Ismail \& Intan safinas Mohd Ariff albakri. (2012). A Study on The Relationship Between Learners' Informal Exposure to English and Their Achievement in the Malaysia University English Test MUET. English Language Journal. 5(1): 94-112. Universiti Pendidikan Sultan Idris Publisher.

Gedera, D. S. P. 2011. Integration of weblogs in developing language skills of ESL learners. International Journal of Technology in Teaching and Learning, 7(2): 124-135.

Intan Safinas Mohd Ariff Albakri, Noriah Ismail. (2013). Undergraduates Students' Anxiety in Learning English. Malay Civilisation Journal. 8 (1) 2013. ISBN 1674-4271 Publisher: Universiti Pendidikan Sultan Idris, Malaysia.

Merriam, S. B. 1998. Qualitative research and case study applications in education. San Francisco, CA: Jossey-Bass.

Mohammadi, N., Ghorbani, V. and Hamidi, F. 2011. Effects of e-learning on Language Learning. Procedia Computer Science, 3: 464-468.

Noriah Ismail, Supyan Hussin \& Saadiyah Darus. (2016). Investigating the Impacts of IQ-Write Online Writing Program toward ESL Students' Attitude and Interest in Learning Academic Writing. (2016). The International Journal of The Interdisciplinary Educational Studies. 11, (1):21-34.

Noriah Ismail, Intan Safinas Mohd Ariff Albakri (2013). The Use of Students' Personal SelfReflective Blog for Academic Writing Activities among ESL Tertiary Level Students. $5^{\text {th }}$ International Conference on Education and New Learning Technologies EDULEARN13: Barcelona Spain: Pages 4617-4621

Rezaee, A. A. and Oladi, S. 2008. The effect of blogging on language learners' improvement in social interactions and writing proficiency. Iranian Journal of Language Studies, 2(1): 73-88.

Supyan Hussin, Rehab Omar Salem Aboswider, Noriah Ismail \& Soo Kum Yoke (2016).Exploring Instructors Rationale and Perspectives in Using Blogs as a Tool for Teaching English as a Second Language. English Language Teaching Journal Canada: 9 (10) 142-155

Top, E., Yukselturk, E. and Inan, F.A. 2010. Reconsidering usage of blogging in preservice teacher education courses. Internet and Higher Education, 13: 214-217.

Warschauer, M. 2010. New tools for teaching writing. Language Learning \& Technology,14(1): 3-8.

Zawilinski, L. 2009. HOT Blogging: A Framework for Blogging to Promote Higher Order Thinking. The Reading Teacher, 62(8): 650-661. 